\title{
Conditional Tax Competition in the American States
}

\author{
Vincent Arel-Bundock, Université de Montréal \\ Srinivas Parinandi, University of Colorado, Boulder
}

April 20, 2017

\begin{abstract}
Cross-border commercial activity raises issues in federations, where multiple jurisdictions can claim the right to tax the same income. In the United States, this coordination problem is resolved by splitting the tax base according to the geographic distribution of firms' sales, capital, and labor. The weight of each factor is determined on a state-by-state basis, which opens room for competitive legislative behavior. In this complex issue area, however, policymakers must invest a lot of resources to monitor competitors, evaluate policy alternatives, and shepherd tax reform through the legislative process. This implies that highly professional legislatures should be more responsive to the policies of nearby states. We consider data on most American states over the 1986-2013 period and find strong evidence of conditional spatial dependence. Our findings suggest that policy diffusion may often be moderated by institutional and political factors.
\end{abstract}

\footnotetext{
${ }^{0}$ The authors thank André Blais, William Fox, Rob Franzese, Jude Hays, Jeff Harden, Jennifer
} 
Interstate commercial activity raises significant issues in federations, where multiple jurisdictions can claim the right to tax the same income. If a single dollar of profit is taxed twice, firms have less incentives to invest or engage in activities that span multiple states, and this may hamper economic growth.

In the United States, this coordination problem is resolved by splitting the corporate tax base according to the geographic distribution of firms' sales, capital, and workforce. The weight of each factor in the apportionment formula is determined on a state-by-state basis, which opens room for competitive legislative behavior: states can reduce the capital and labor weights of their formulas in hope that this will attract new investments.

In this paper, we argue that certain states are better positioned than others to engage in this form of tax competition. As we explain below, the apportionment formula is a complex instrument, and its effects are difficult to anticipate. Moreover, legislators cannot rely on partisan heuristics or on coherent signals from firms and voters when they set policy in this domain. In that context, legislators must invest a lot of resources to monitor competitors, evaluate policy alternatives, and shepherd tax reform through the legislative process. This implies that highly professional legislatures, which have access to more time and staff than semi-professional legislatures, should find it easier to redefine their tax base in response to exogenous shocks to the competitive environment. In other words, formula-based tax competition should be characterized by conditional spatial dependence.

We begin our analysis by taking a closer look at the mechanics of tax coordination between American states. We explain that tax base apportionment schemes can have important distributional consequences, and that the lack of policy coordination at the national level can give rise to inter-state competition.

Then, we use spatial econometric techniques to study data on most American states over the 1986-2013 period. We find strong patterns of regional interdependence in the definition of taxable corporate income. This is consistent with the idea that state governments compete, not just over the more visible nominal tax rates, but also along other policy vectors. Tax codes are extremely complex, and that complexity gives legislatures opportunities to competitively redefine the tax base in a bid to attract investors.

This straightforward economic story serves as a useful overarching narrative, but it suffers from two important (political) blind spots. First, even if tax policies are clustered regionally, there remains considerable heterogeneity in the timing and speed of reforms across neighboring states. Explaining the sources of such heterogeneity is, in and of itself, an important goal for political science. Moreover, differences in the speed at which policies spread from state to state offer an opportunity to draw broader lessons for the field of legislative studies: They allow us to study

Wolak, the Editors and reviewers of the Journal of Public Policy. 
how political and institutional factors condition policy diffusion. By looking at these conditioning effects, we move closer to the mechanisms that carry policies across borders.

Second, standard economic theories of tax competition often fail to explain why, empirically, tax rates are rarely driven all the way down to zero. In Why is there no race to the bottom in capital taxation?, Plümper, Troeger and Winner $(2009,761)$ argue that even if all governments are subject to the pressure of capital mobility, competitive legislative behavior is often held back by societal demand for positive tax rates: States are "restricted by budget constraints and equity norms". Our paper suggests that this demand-side explanation must be supplemented by a supply-side one: Governments do not always have the institutional capacity to use complex policy levers in order to attract investors. Indeed, a lack of professionalism can impede state governments' responsiveness to competitors' policies.

In short, our work finds strong evidence of policy diffusion across states, but also highlights important limits to standard theories of tax competition. We emphasize the importance of legislative capacity for policy diffusion, and argue that institutional factors can explain why, after 30 years of formula-based tax competition, American states have yet to reach the logical end point of this race-to-the-bottom.

To develop our explanation, we build on seminal work by authors such as Charles Shipan and Craig Volden, who have studied the relationship between professionalism and policy diffusion. It is well established that resource-rich and highly professional legislatures are innovators and thought leaders-in many fields, while resourcepoor and semi-professional legislatures tend to emulate the actions of their better resourced neighbors (Walker, 1969; Shipan and Volden, 2008). Our paper adds to this body of knowledge by showing that professionalism does not just spur more innovation, but that it also increases the capacity of states to strategically emulate policy in order to stave off competitive threats from neighbors. Conversely, a lack of professionalism introduces friction in diffusion processes, and can impede policy convergence.

Importantly, we show that professionalism, by itself, does not necessarily predispose a government to adopt a particular apportionment formula. This is because, as we explain below, the "optimal" policy for a given state is context-dependent; it is a function of competitors' policies. As a result, professional legislatures need not converge toward a specific policy. Rather, the main advantage of such governments is that they are better able to take decisive action in response to changes in the competitive environment. In other words, legislative capacity allows state governments to be more strategic and more responsive.

Taken together, our results strongly indicate that political and institutional factors moderate policy diffusion, and suggest that studying how such factors can speed up or slow down diffusion is a promising avenue for future research. 


\section{TAX COORDINATION IN THE AMERICAN STATES}

Several problems arise when the taxable activities of a firm span many jurisdictions. One major concern is the possibility that a single dollar of profit will be taxed by multiple states. This, of course, would reduce incentives to engage in interstate commerce and cross-border production operations, and ultimately hurt investment and economic growth. Two main strategies have been devised to curtail double taxation.

The first approach, separate accounting, considers the operations that a firm runs in each state as if they were conducted by different legal entities. Under this system, transactions between subsidiaries of a single company must be conducted at "arm's length", that is, at market price. Profits are then computed and taxed on a state-bystate basis. Separate accounting is the cornerstone of the current international tax system. 1

The American states use a second approach to split the tax base: formulary apportionment. ${ }^{2}$ The profits of all US branches of a firm are added up to calculate the company's total profits. This aggregate is then apportioned to each state based on the geographic distribution of firm activity. Typically, profits are split according to the shares of national sales, payroll, and property that the firm holds in each state. The tax liabilities of a firm in state $j, \tau_{j}$, are thus computed as follows:

$$
\tau_{j}=t_{j}\left(w_{j}^{P} \frac{P_{j}}{P}+w_{j}^{L} \frac{L_{j}}{L}+w_{j}^{S} \frac{S_{j}}{S}\right)
$$

where $t_{j}$ is state $j$ 's corporate tax rate; $w_{j}^{f}$ is the weight of factor $f$ in $j$ 's apportionment formula; $P_{j} / P, L_{j} / L$, and $S_{j} / S$ refer to the share of total property, payroll, and sales that occur in $j$.

Historically, most states have weighted the three factors equally: $w_{j}^{P}=w_{j}^{L}=$ $w_{j}^{S}=1 / 3$. In recent years, however, several jurisdictions have increased the value of the sales factor relative to the other two. Typically, emphasizing the sales factor means giving it double-weight $\left(w_{j}^{P}=w_{j}^{L}=1 / 4 ; w_{j}^{S}=1 / 2\right)$, or adopting a singlesales (or sales-only) formula $\left(w_{j}^{P}=w_{j}^{L}=0 ; w_{j}^{S}=1\right.$ ), but some states choose intermediary positions for some years.

\footnotetext{
${ }^{1}$ The arm's length principle has often been criticized because it is difficult to implement; separate accounting allows firms to re-allocate profits, shifting income from high to low-tax jurisdictions. Joint Committee on Taxation (2010) presents several case studies to illustrate the problem.

${ }^{2}$ The core contribution of this paper relates to the choice of formula, not to the choice of tax system itself (i.e., formula apportionment vs. separate accounting). On the latter, Hines (2010) finds that apportionment formulas are poor predictors of firm profits, and argues that the unitary tax regimes that use such formulas can produce substantial economic distortions. Riedel and Runkel (2007) offer a more positive theoretical outlook on apportionment formulas.
} 


\section{ECONOMIC CONSEQUENCES OF APPORTIONMENT FORMULAS}

States' choice of an apportionment formula has three principal economic consequences, which relate to (1) government revenue, (2) taxation of the underlying factors of production, and (3) arbitrage and externalities.

Government revenues. A first important economic consequence of formula choice is highlighted by Gupta et al. $(2009,237)$, who "find that states with a double-weighted sales factor experience lower revenues than do states with an equally-weighted sales factor". This is in line with the results of ?, and of the Illinois Economic and Fiscal Commission (2002) who estimated that Illinois lost \$96 million in 2001 due to the adoption of a single-sales factor formula. Giving more weight to the sales factor can reduce government revenue.

A tax on factors of production and sales. Second, a corporate income tax that is allocated using an additive apportionment formula can be seen as three separate taxes on the underlying components (i.e., labour, capital, and sales). This much should already have been clear from a cursory look at Equation 1, but McLure (1980) demonstrates formally that increasing the sales weight amounts to converting the corporate income tax into a sales tax ${ }^{3}$ Of course, this could have important distributional implications, because sales taxes tend to be regressive.

As in the case of sales, the payroll and property weights can be viewed as implicit taxes on employment and capital. This, in turn, suggests that high payroll and property formula weights could discourage firms from expanding their production operations in states that use an equal weights formula. It also implies that increasing the sales weight (and reducing the payroll and property weights) could attract local investment in capital and labour.

This intuition is in line with the theoretical work of McLure (1980), Gordon and Wilson (1986), Anand and Sensing (2000), and it has already been subjected to several empirical tests. For instance, Goolsbee and Maydew (2000) find that "reducing the payroll weight from one-third to one-quarter increases manufacturing employment around 1.1\%". This result is generally consistent with other works by Klassen and Shackelford (1998) and Gupta and Hofmann (2003).

\footnotetext{
3"Unless firms operate predominantly within one state, most of the sales-related part of the profits $\operatorname{tax}$ is equivalent to a sales tax. While the equivalence is not total, it is quite strong for multistate corporations. Finally, to the extent that payrolls and property are more concentrated in a few states than are sales, the payroll and property-related portions of the state profits tax are more nearly true profits taxes than is the sales-related portion but only for the states in which production is concentrated (McLure, 1980, 334)."

${ }^{4}$ But see? who fails to find a significant association between formula choice and economic activity.
} 
Externalities and arbitrage. The third important economic consequence is that the lack of a harmonized apportionment formula across US states opens up room for arbitrage by firms which operate in multiple jurisdictions. As Gordon and Wilson $(1986,1357)$ note, when "a sales component to the tax is added, there are incentives for the cross-hauling of output, with production in low tax rate states sold in high tax rate states, and conversely."

To understand how such a strategy would work in practice, consider this simple numerical example: two states apply identical tax rates $\left(t_{a}=t_{b}=5 \%\right)$, but different apportionment formulas. State A weighs payroll and sales equally, while State B only considers sales. Firm $X$ has total profits $(\pi)$ of $\$ 1$ million from sales that are evenly spread across the states. Now consider $X$ 's tax burden in two different scenarios: (Scenario 1) all employees are located in State A, (Scenario 2) all employees are located in State B. Total tax liabilities $(T)$ are computed as follows:

$T=\pi\left[t_{a}\left(w_{a}^{L} \frac{L_{a}}{L}+w_{a}^{S} \frac{S_{a}}{S}\right)+t_{b}\left(w_{b}^{L} \frac{L_{b}}{L}+w_{b}^{S} \frac{S_{b}}{S}\right)\right]$

$T=1,000,000\left[0.05\left(.5 \frac{1}{1}+.5 \frac{1}{2}\right)+0.05\left(0 \frac{0}{1}+1 \frac{1}{2}\right)\right]=62,500 \quad$ (Scenario 1$)$

$T=1,000,000\left[0.05\left(.5 \frac{0}{1}+.5 \frac{1}{2}\right)+0.05\left(0 \frac{1}{1}+1 \frac{1}{2}\right)\right]=37,500 \quad($ Scenario 2$)$

This example shows that moving production operations to State B allows Firm $X$ to minimize its tax burden. ${ }^{5}$ In the next section, we discuss how states can manipulate formula weights to attract investment, and how this strategy has hampered policy coordination.

\section{FORMULA CHOICE - HARMONIZATION OR COMPETITION?}

Theoretical work suggests that social welfare maximization does not require that states adopt a specific formula, but rather depends on the harmonization of the formulas used in different jurisdictions (Anand and Sensing, 2000). Accordingly, much effort has been expended in order to improve state coordination in that policy domain. 6

Those efforts, however, have been hampered by the strong economic pressures that we highlighted in the previous section. Since increasing the sales weight of the

\footnotetext{
${ }^{5}$ This example is, of course, simplistic, as it ignores the various provisions put in place to eliminate "nowhere income", such as throwback rules.

${ }^{6}$ Two milestones are the creation of the Uniform Division of Income for Tax Purposes Act (UNDITPA) in 1957 and the Multistate Tax Compact and the Multistate Tax Commission in 1967. See Weiner (1999) for a concise overview of these historical developments.
} 
apportionment formula can attract investment, it is rather unsurprising to see that many states have used this policy instrument strategically. This competition was given a boost in 1978, when the Supreme Court ruled that Iowa's single factor sales formula did not run afoul of the Due Process or Commerce clauses. In the wake of this decision, many other states have increased the weight that they accord to sales in their apportionment process.

Several authors have attempted to explain why harmonization has not occurred. Anand and Sensing (2000, 183), for instance, develop "a two-state equilibrium model of location choice by firms", and "show that aggregate social welfare is maximized when both states choose the same apportionment formula, regardless of which formula is chosen." However, the authors also find that at least one state will always have an incentive to deviate from the coordinated solution. 1 Similarly, Edmiston (2002) models tax competition via formula apportionment as a prisoner's dilemma, where states have incentives to undercut one another by adopting a sales-only formula. This article also suggests that states' decisions in that respect can have important revenue consequences. 8

Perhaps most relevant to our own work is an article by Omer and Shelley (2004), who find that changes in a state's apportionment formula tend to be associated with changes in geographically contiguous states' policies. Like Omer and Shelley (2004), we analyze the determinants of state income tax competition based on apportionment formulas. However, unlike Omer and Shelley, who look at how geographic contiguity and some political (gubernatorial rather than legislative) factors separately (additively) drive competition, we propose and find evidence for a theory in which legislative capacity moderates income tax competition-based policy diffusion between the states. 9

\footnotetext{
${ }^{7}$ Anand and Sensing (2000) also point out that importing and exporting states may face different incentives with respect to formula choice.

${ }^{8}$ The idea that states should increase the sales weight of their apportionment formula follows quite naturally from our discussion of economic consequences in Section 2 . Our reading of the literature on the topic is that this view is not controversial, but it is worth noting that some authors have made alternative arguments. For instance, Wellisch (2004) argues that states face incentives to shift the apportionment formula toward immobile factors such as labor, and Pinto (2007) develops a model in which "regional governments strictly prefer a formula that exclusively weighs the production proportion to any other alternative".

${ }^{9} \mathrm{An}$ important limitation of our study is that we consider the choice of apportionment formula in isolation from other policy choices. This is a well-known problem in the tax competition literature, where dozens of studies have been published on inter-jurisdictional dependence in the use of specific fiscal instruments (e.g., nominal corporate income tax rates, $\mathrm{R} \& \mathrm{D}$ credits), without considering that governments may react strategically to changes in their neighbors' policies by pulling on different economic levers (e.g., capital depreciation schedules, carry-forward rules). Unfortunately, our research design does not allow us to account for a state government's full portfolio of tax instruments when studying competition. As such, our regression estimates may thus fail to capture the strategic responses of states who choose to answer to competitors by changing a policy other than the apportionment weight. Empirically, this suggests that our estimates could suffer from attenuation bias.
} 


\section{CONDITIONAL SPATIAL DEPENDENCE IN TAX POLICY}

The works cited above suggest that apportionment formulas affect corporate investment behavior. This, in turn, creates a new vector of competition for investmentseeking state governments who can manipulate the sales weight to attract investors. In this section, we shine light on the phenomenon of formula-based tax competition by drawing on the rich literature on policy diffusion in the American states. Then, we refine the analysis by arguing that in complex policymaking environments, a legislature's response to competitive pressures is conditionned by its capacity and professionalism.

\subsection{Formulary Apportionment and Policy Diffusion in the American States}

Cross-state competition over policy outputs has long been featured in the literature on state policy diffusion in the American states. Looking at areas such as state lotteries (Berry and Berry, 1990), welfare (Peterson and Rom, 1990; Rom, Peterson and Scheve, 1998; Volden, 2002), and smoking (Shipan and Volden, 2008), a number of scholars have shown that economic competition is a prominent driver of policy diffusion or interdependence across the states.

By increasing the sales apportionment weight, states can compete to attract corporate investment. However, legislators may be uncertain about whether the corporate investment-generating benefits of this policy change outweigh losses to government revenue. Increasing the sales weight deprives state governments of revenue that can fund popular programs. 10

Uncertainty about the economic consequences of increasing a corporate tax's sales weight can generate disagreement among co-partisan legislators about the merits of increasing the sales weight, and can weaken party heuristics about how party members should vote: Some Democrats may support increasing the sales weight to retain and attract job-creating investments while other Democrats may oppose reducing government revenues by decreasing property and payroll weights.

Legislators can also face conflicting signals from firms, since apportionment formulas have heterogeneous effects: Increasing the sales weight benefits corporations that have large in-state production facilities and a small amount of local sales. Conversely, firms with small production facilities but many in-state customers prefer a lower sales apportionment weights. This means that this policy cannot simply be

\footnotetext{
${ }^{10}$ In 2002, the Illinois Economic and Fiscal Commission'a policy study group consisting of Illinois legislators'reviewed the policy impacts of the Illinois legislature's 2000 decision to switch to a singlesales corporate tax factor. The commission admitted that "Illinois lost approximately $\$ 96$ million in state and local tax revenues in 2001 due to the single-sales factor" but argued that "the State would have risked losing additional large multinational corporations to other states that now have the single-sales factor incentive" absent the adoption of the single-sales factor (Illinois Economic and Fiscal Commission 2002: 6).
} 
understood as a tax cut that would benefit all firms. In testimony to the Maryland legislature in 1999, for example, Philip Morris opposed Maryland's adoption of a single-sales factor on the grounds that this action "would provide an unfair advantage to certain corporations" (McCoy, 1999).

\subsection{Legislative Professionalism Moderates the Diffusion of Tax Policies}

Facing conflicting signals from the business community and uncertainty about the policy's effects, legislators can learn from the experiences of other states and emulate "successful" peers (Volden, 2006). However, not all legislatures have the same capacity to observe, assess, and formulate responses to tax reforms in other states. In fact, legislative professionalism - or a legislature's resource capacity in terms of the amount of staff, compensation, and time (Squire, 2007) - can affect the propensity of governments to respond to changes in competitors' policies.

Several scholars have shown that professional legislatures are more likely to adopt new policies than semi-professional legislatures (e.g., Carter and LaPlant, 1997; Mossberger, 2000; Boushey, 2010). In this line of work, the effect of legislative professionalism on a state's policies is often modelled as additive and independent of other states' behavior, but an emerging strand of literature points out that professionalism can also condition the process of policy diffusion. For instance, Shipan and Volden (2006) study the "bottom-up" diffusion of antismoking policy from municipal to state governments and find that highly professional state legislatures are more likely to emulate antismoking policies that have already been adopted by within-state municipalities. Shipan and Volden (2014) report similar findings.

We follow in the footsteps of these authors, but consider a very different issue area: instead of looking at how legislative professionalism facilitates the diffusion of public health initiatives, we argue that professionalism can improve a state's ability to respond to rivals' tax policies. This distinction between issue areas matters, because it ties our respective arguments to very different kinds of policy diffusion mechanisms (Shipan and Volden, 2008). On the one hand, youth antismoking laws are a classic example of a public health policy area where states can cooperate, working together to overcome a shared social problem. There, legislative professionalism can facilitate diffusion because professional legislatures have more staff and time to contact officials in peer states who can help streamline policy responses around shared best practices.11] On the other hand, where states compete against one another, governments may not want to work together, and the ability of states to respond to their rivals' policy actions can be stunted due to resource insufficiency. There, we argue that legislative professionalism allow states to respond to economic challenges from

\footnotetext{
${ }^{11}$ This is exactly what is happening currently with respect to the ongoing public health crisis of heroin addiction across the United States. Many states have worked together and devised a shared strategy to contain and rollback the epidemic.
} 
rivals.

To see why professionalism acts as a catalyst for tax competition, consider the conditions that need to be met for legislators to behave strategically in this field. First, they must be aware that other states are manipulating their apportionment formulas. Second, to assess the costs and benefits of the policy change, they must be able to anticipate how it would affect economic investment and revenue generation in their districts. Third, legislators need the know-how to craft corporate tax policies that effectively respond to competitors and are attractive to investors. Finally, they must expend the resources and political capital necessary to write new law and shepherd it through the legislative process.

In semi-professional legislatures, information gathering, policy assessment, and legislative action tend to be more difficult, because the typical legislator has limited access to both time and expertise. For instance, she may hold outside employment in addition to her legislative responsibilities (Kousser 2005), or may simply be unaware of the competitive threat posed by rival states on technical issues like formulary apportionment. Even if the legislator is aware of other states' competitive behavior, she may not be able to obtain district-specific analysis on how an apportionment change would influence corporate investment and revenue streams relevant to her constituents. This is because, with small staff sizes and short legislative session lengths, typical members of the state legislature have more limited exposure to outside experts and specialist legislators who serve on fiscal committees. In that context, time and resource-strapped politicians may choose to expend efforts on the development of legislative proposals which are more visible to the electorate, instead of focusing on abstruse questions like apportionment formulas. As a result, it seems reasonable to expect that semi-professional legislatures will be relatively slow to respond to threats from rival states.

In contrast, even a typical, non-committee member in a professionalized legislature has resources to devote to low-visibility issues outside her purview of expertise. That legislator does not typically hold employment outside of her legislative responsibilities, she has more interactions with other legislators (including expert committee members), has access to more staff, and can also call upon the expertise of better-resourced agencies that exist to help legislators with their job responsibilities. Even though this legislator may not have originally been an expert on tax apportionment policy, the resources of time and staff accruing from professionalism could allow her to gain sufficient expertise to push for reform. In that context, expert committee members may also be more willing to pursue tax reform if they can depend on the interest and support of non-committee legislators. In other words, professionalism reduces the knowledge gap between experts and non-experts in the legislature, and it facilitates information acquisition, policy assessment, and legislative action. The net result, we argue, is an increase in the likelihood that a state will respond to tax policy competition from rivals. 
Of course, the cost of engaging in formula-based tax competition must not be overstated. Even in semi-professional contexts, information about formulary apportionment is available for the motivated legislator, ${ }^{12}$ and the set of available policy options is relatively limited. Still, information gathering, policy assessment, and the formulation and adoption of legislative responses is never costless. In semiprofessional legislatures, these costs can often slow down or even stop legislative action; professionalism can make a government's policies less insular, and more responsive to legislative actions taken across state lines.

\subsection{Illustration: The cases of Michigan and New Hampshire}

There is ample qualitative evidence to support our argument. Consider a comparison of legislative operations in two states: Michigan and New Hampshire. At the time of writing, Michigan applies a single-sales apportionment model, while New Hampshire uses a $50 \%$ sales factor. Michigan also has one of the most professional state legislatures in America, while New Hampshire consistently ranks at or near the bottom of the Squire scale.

In Michigan, the resources available to a non-committee non-expert legislator who wants to inquire about tax policy are substantial. First, there is the resource of time: Michigan's full legislature often meets and conducts business year-round. This means that non-committee non-expert legislators have more opportunity to contact specialized committee members and staff to inquire about the potential district-specific effects of tax reform. Second, there is the resource of staff: Michigan's House of Representatives and Senate each maintain permanent fiscal agencies who share the same purpose of "providing confidential nonpartisan expertise to the House (and Senate) Appropriations Committee(s)" in addition to "all other members of the House (and Senate) on all legislative fiscal matters." (Michigan House Fiscal Agency, 2017, Michigan Senate Fiscal Agency (2017a)). The fiscal agencies are not small operations; they both work year-round and each include over $23 \mathrm{mem}$ bers (Michigan House Fiscal Agency, 2017, Michigan Senate Fiscal Agency (2017b)). The staff in these agencies hold a wide range of expertise that may be useful for legislators: they host fiscal analysts who "prepare reports and documents to assist legislative deliberations; and prepare special reports at the request of Representatives," economists, who "respond to Representatives' inquiries regarding state tax revenue, revenue sharing, and other economic issues," and legislative analysts, who provide information including "a description of the problem being addressed, arguments for and against [a] bill, and positions of interested organizations" (Michigan House Fiscal Agency, 2017). The depth and quality of the staff at the fiscal agencies, combined

\footnotetext{
${ }^{12}$ Accounting firms publish commercial tax guides which can inform legislators' actions, and business groups often act as transmission belts across state lines for information about the nitty-gritty of tax law.
} 
with Michigan's long legislative session, gives typical legislators, who tend not to be experts on tax policy and usually do not serve on committees dealing with tax and fiscal policy, the opportunity and means to develop expertise about tax apportionment issues. This, we argue, increases the likelihood that the state legislature as a whole will respond to apportionment threats from other states.

In New Hampshire, on the other hand, the resources available to a non-committee non-expert legislator who wants to inquire about tax policy are minimal. First, there is a shortage of time: New Hampshire's full legislature meets for 45 legislative days a year and usually concludes its session by mid-summer of each year. This means that there are limited opportunities in session for dialogue between expert committee member legislators and non-committee non-expert legislators, and that the legislative agenda can be very crowded.Moreover, several members of New Hampshire's "citizen legislature" hold non-legislative employment, which further limits the time they can invest in learning about technical policy questions. Second, there is also a shortage of staff: Unlike Michigan's fiscal agencies that bring together fiscal analysts, economists, and legislative analysts to help legislators, New Hampshire's "Legislative Budget Assistant" consists mainly of accountants, and chiefly audits state agencies and provide technical budgetary assistance to committees, rather than the broadbased analysis that is provided by the Michigan agencies. Moreover, the staff size of the New Hampshire Legislative Budget Assistant's Budget Division is much smaller than in Michigan's agencies: seven versus forty-nine, even if New Hampshire has a higher number of legislators than Michigan.

That is not to say that New Hampshire legislators are unable to acquire relevant information about formulary apportionment, or that they are never exposed to such information. In 2014, for example, the Department of Revenue Administration gave a presentation about tax policy to the state's House Ways and Means Committee. That presentation covered several aspects of business taxation, and mentioned apportionment formulas in peer states. In the end, however, representatives from the Department of Revenue Administration recommended more "legislative study" on the grounds that a change in the apportionment method would engender an "unknown fiscal impact to state revenues" (New Hampshire Department of Revenue Administration, 2014). In making this recommendation, the Department of Revenue Administration explicitly referred to a failed 2012 legislative attempt to establish a committee to study the apportionment of business profits. ${ }^{13}$ This failed attempt, and the call for deeper study, highlight the transaction costs that can be involved in conducting policy assessment. In semi-professional legislatures, these costs weigh heavier than in well-staffed, well-resourced legislatures.

In sum, our argument hangs on the capacity-augmenting benefits of increased

\footnotetext{
${ }^{13}$ Bill 1209, establishing this committee, passed both the House and Senate but failed after an unsuccessful amendment was introduced.
} 
legislative professionalism: when interstate competition occurs in complex or less visible policy areas, highly professional legislatures are more likely to seek out ways to redress competitive balance. As a result, we expect highly professional legislatures to have spatially interconnected and less insular policies than less professional ones.

\section{EMPIRICAL ANALYSIS}

The goal of this section is to assess three empirical implications from the preceding theoretical discussion. First, if there is formula-based tax competition between states, we should observe convergence over time toward a $100 \%$ sales weight. Second, if legislatures respond to the policies of their competitors, policy changes should be geographically clustered, with similar (i.e., proximate) states adopting similar policies. Third, the spatial diffusion of policies should be moderated by legislatures' professionalism: high-capacity governments should be more responsive to other states' policy changes.

\subsection{Exploratory data analysis}

States that tax corporate income typically choose between one of three apportionment regimes: $100 \%$ sales, double-weighted sales (i.e., $50 \%$ sales, $25 \%$ payroll, $25 \%$ capital), or equal weights for each factor (i.e., 33\% sales, 33\% payroll, 33\% capital). When a legislature decides to move from one regime to another, it usually does so incrementally, raising the sales weight in stepwise fashion by a few percentage points per year. For instance, when Pennsylvania decided to switch from double-weighted sales to $100 \%$ sales, it did so in a staggered manner: the state raised its sales weight from 50 to $60 \%$ in 1999, and then gradually moved from 60 to $100 \%$ over the 2005 2013 period.

We assembled data on the apportionment formulas of most American states $\sqrt{14}$ over the 1986-2013 period.15 In our sample, payroll and capital weights always move in the inverse direction of the sales factor. Therefore, we can consider the latter as dependent variable in all empirical tests.

As a first cut, it is useful to look at temporal variation in our variable of interest. Figure 2 shows over-time changes in the average sales weight across all states in our

\footnotetext{
${ }^{14}$ Because our theory is operationalized using measures of geographic contiguity and distance, we leave Alaska and Hawaii out of the analysis. We also exclude states that do not impose a traditional corporate income tax (Nevada, South Dakota, Texas, Washington, Wyoming, and post-2005 Ohio). Finally, we exclude the state of Mississippi, since it uses industry-specific apportionment formulas. In the robustness checks section, we discuss alternative case selection strategies.

${ }^{15}$ We chose 1986 as the first year of the sample because it shortly predates the time when most states began tweaking their corporate tax apportionment formulas, and because finding reliable information for the period before that year proved to be very difficult.
} 
sample. The pattern is clear: while the modal policy in the mid-1980s was to weigh each factor equally, we see a gradual increase in the sales factor weight over the past three decades. In 1986, only $7 \%$ of the states in our sample had adopted a sales-only formula; by 2013, that proportion had risen above $40 \%$. Likewise, the proportion of states using equal weights dropped by about 50 percentage points over the same window. Importantly, no state has reduced the sales weight of its apportionment formula during the period of study. This pattern is consistent with the idea that interstate competition leads to policy convergence across jurisdictions.

\section{[FIGURE 2 ABOUT HERE]}

The second important dimension to consider relates to the spatial distribution of policy. Figure 3 shows the sales apportionment weight of each state in 2012. As this map makes clear, there are distinct geographical clusters, with neighboring states often adopting similar policies. This visual pattern is striking, and it also appears to be statistically significant: tests using Moran's I reject the null hypothesis of no spatial autocorrelation in most years of the sample.

[FIGURE 3 ABOUT HERE]

Figures 2 and 3 suggest that two of the empirical implications of our theory are correct (policy convergence and geographic clustering). In the next section, we develop a spatial econometric model to assess the third implication of our theory, that is, we test whether spatial policy diffusion is conditioned by legislatures' professionalism.

\subsection{An econometric model of conditional spatial dependence}

Our dependent variable is the sales apportionment weight, measured on a continuous scale from 33 to 100 . In terms of our explanatory variables, we use spatial econometrics to assess the influence of other states on the choices of state i (Beck, Gleditsch and Beardsley, 2006; Franzese and Hays, 2007). This is typically achieved by adding a "spatial lag" variable to the right side of a regression equation. This variable essentially acts as a weighted average of other states' policies, with weights chosen to represent theorized patterns of interdependence between states. In the state policy diffusion literature, for instance, scholars often argue that state i's policy choices are particularly sensitive to nearby competitors, so they give design spatial lag variables that attribute more weight to proximate states (Berry and Berry, 1990; Berry and Baybeck, 2005; Volden, 2006; Pacheco, 2012).

Typically, analysts consider the effect of a proximate state's policies to be separate and independent from the effect of other non-spatial variables on policy choice. As a result, spatial lag variables tend to be entered as additive components in regression models of policy choice. This assumption of additive spatial influence makes sense if one believes that the effect of neighbors' policies on state policy choice is not amplified or ameliorated by the presence of other independent variables. However, 
if another variable conditions the responsiveness of a state to spatial stimuli and we fail to take this conditioning effect into account, then our model will produce biased estimates.

In this paper, we argue that legislative professionalism conditions governments' response to interstate competition. To test this, we fit a model using Ordinary Least Squares with spatial-lags and multiplicative interactions. The baseline specification is this:

$$
y_{i t}=\lambda_{1} W f_{i, t-1}+\lambda_{2} W f_{i, t-1} p_{i, t}+\lambda_{3} p_{i, t}+\boldsymbol{\beta} \boldsymbol{X}+\varepsilon_{i, t},
$$

where $f_{i, t}$ is the sales weight of the apportionment formula in State $i$ at time $t$; $W$ is a matrix of weights which represent the influence that every other state has on $i$ 's policy (Neumayer and Plümper, 2012, Eq.7);16 $p_{i, t}$ is a column vector which represents State legislative professionalism (Squire, 2007); $\boldsymbol{X}$ is a vector of control variables and state fixed effects; and $\varepsilon$ a disturbance term.

To guard against omitted variable bias, we control for a vector $\boldsymbol{X}$ of control variables, which includes the log of a state's GDP. We also add the log of a state's unemployment rate to reflect the possibility that states with high unemployment could face different corporate tax demands.

Our main quantity of interest is $\lambda_{2}$, which represents the conditioning effect of legislative professionalism on policy interdependence between jurisdictions. If $\lambda_{2}$ is positive, then we can conclude that professional legislatures are more responsive to changes in other states' policies. In other words, this specification allows us to account for heterogeneity in responsiveness to competitive pressure.17

\subsection{Connectivity matrix specification}

Before estimating the model described in Equation 3, we must decide how to specify the $W$ connectivity matrix. This decision matters, because different weights in $W$ imply different theories of policy diffusion. We consider four main possibilities.

First, there is long tradition of work in economics which shows that geography drives and constrains investment location decisions (Krugman, 1991; Porter, 1998). When firms decide where to invest, they must often choose between nearby states

\footnotetext{
${ }^{16}$ All the connectivity matrices we consider were row-normalized.

${ }^{17}$ Neumayer and Plümper (2012) also propose models which can account for heterogeneity in exposure to competitive pressures. In the context of this paper, we do not consider the possibility that states could be a function of the "aggregate" policies of all states. It seems plausible, for instance, that laggards and first movers face different incentives. Unfortunately, existing theoretical models of formula choice only consider the decision in the context of two or three actor models, and developing a formal model of formula choice in the multi-state context lies beyond the scope of this article. From a firmlevel perspective, our evidence should thus be interpreted as representing the competitive pressure that arises between the few proximate states that actually compete for any given investment decision.
} 
in order to protect existing relations with customers and suppliers. For example, in 2006 Honda of America decided to build a new automobile factory in Indiana. At the time, Honda's main base of operations was in Ohio, and it wanted to preserve its relationships with 150 supplier locations in that state. Honda received bids from five states and ultimately chose Indiana in part due to fiscal inducements, but also largely because of its proximity to Ohio (Hannah, 2006; Maynard, 2006).

If geography drives investment decisions, legislatures should feel more pressure to reform their tax codes when nearby states engage in a race-to-the-bottom; distance should be an important driver of tax competition. This basic intuition explains why geographic proximity is, by far, the most common measure of influence in empirical studies of tax competition, and why it is an ubiquitous feature of gravity models of trade and investment. To remain consistent with prior works on tax competition, we present results using a measure of inverse distance between states as weights in the $W$ matrix.

Second, Case, Rosen and Hines (1993) and Volden (2006) suggest that policies can spread across states, not simply due to their geographic proximity, but also based on the similarity of their economic structures. Indeed, it seems reasonable to expect that a state's tax policies can sometimes have an influence on far-flung jurisdictions. For instance, if two distant states have similar resource endowments and present similar investment opportunities, they could compete to attract the same businesses. In that context, policy diffusion may be a function of economic similarity between states, rather than geography per se. To account for this possibility, we estimate results using two alternative spatial lag matrices. The first is constructed using data from the 2007 Commodity Flow Survey conducted by the US Census Bureau. 18 For each pair of states, we take the correlation between the states' baskets of commodity exports. The other spatial lag uses the squared differences in states' personal income per capita.19

Third, an interesting possibility is that state legislators wear ideological blinders when looking for policies to emulate. If this is the case, legislators could be influenced by co-partisans, but not by legislators from a different party, and states with similar ideological profiles may adopt similar policies. We thus construct four connectivity matrices to capture this pattern of diffusion. To begin, we consider as "influencers" only the states where both the house and senate are governed by the same party which governs the house and senate of the state being influenced. In alternative specifications of $W$, we take the squared difference in ideological scores between pairs of states, using measures by Berry et al. (2013).

Fourth, Desmarais, Harden and Boehmke (2015) use a network algorithm to

\footnotetext{
${ }^{18}$ US Census Bureau, 2007 Commodity Flow Survey. Shipment Characteristics by origin Geography by NAICS by Commodity: 2007. Retrived from http: //factfinder. census .gov on 2015-12-29.

${ }^{19}$ Each of the economic similarity measures is rescaled to the $[0,1]$, where 1 corresponds to most similar.
} 
study the sequence of adoption across American states for 187 policies. This approach allows them to inductively recover a list of "source" or "influencer" states. The core idea behind this method is that if state $i$ consistently adopts policies after state $j$ has adopted them, then $j$ probably influences policy decisions in $i$. This has obvious implications for our study: if two states are linked through policy networks across 187 issue areas, they may also monitor each other's tax policies. Accordingly, we construct connectivity matrices using the two measures of "source state" produced by Desmarais, Harden and Boehmke (2015).20

These four theoretical mechanisms could plausibly explain tax policy diffusion across American states. Unfortunately, our study design is ill-suited to adjudicate between the relative explanatory power of each mechanism; doing so would require a more fine-grained micro-level analysis, using other methodological tools such as interviews, or developing measures of contact frequency between legislators in different states. As a result, we must remain largely agnostic with respect to the "correct" specification of $W$, and we treat alternative specifications of $W$ as robustness checks rather than competing explanations.21

Below, we present baseline results using a measure of inverse distance between states which is "industry standard" in the tax competition literature. In supplementary materials, we show that our results are robust to eight alternative specifications of the connectivity matrix specification, following the four theoretical mechanisms described above. The stability of our results is interesting, reassuring, but not entirely surprising since geographic, economic, partisan, and policy clusters are strongly correlated.

\subsection{Regression results}

In Table 1, we see that, as expected, the interaction term is positive and statistically significant. This is consistent with the theory developed above.

[TABLE 1 ABOUT HERE]

To assess the substantive significance of the regression results in Table 1 , it is useful to compare counterfactuals for two states with different professionalism scores: New York (high Squire score) and New Hampshire (low Squire score). For the year 2000, the left-most model of Table 1 predicts that the sales weight in New York

\footnotetext{
${ }^{20}$ These are binary measures at the dyad-year level. Since policy diffusion networks must be persistent, and because the measures in question vary a lot within dyads over time, we take the dyad-wise mean of the Desmarais, Harden and Boehmke (2015) "source state" variables over our sampling period.

${ }^{21}$ Note that, in this study, estimating a single regression model with multiple versions of $W$ would be inappropriate. Because the causal mechanisms that each version of $W$ represents are tightly linked, one connectivity matrix will often act as a sort of post-treatment control with respect to another, and the substantive meaning of our coefficient estimates will be unclear. For instance, what does it mean to estimate the effect of "geographic proximity" that is unrelated to "economic proximity"?
} 
should be $80 \%$. For New Hampshire, the same model predicts a sales weight of $49 \%$. Now consider what happens when we artificially increase the sales weight of neighbors (New Jersey and Massachusetts) by 50 percentage points (i.e., from double weight to sales-only). There, the model predicts sales weights of $95 \%$ for New York and 51\% for New Hampshire. In sum, we expect a 15-points increase in New York, but only a two-point increase from the less professional legislature of New Hampshire.

The above example highlights the strong conditioning effect of professionalism, but it may understate the substantive impact of changes in the competitive environment. To get a better sense of the pressure that states face when many neighbors change their policies, we conduct the following simulation: we use the value of each variable in 2000 to predict values of the dependent variable. Then, we add 25 percentage points to each of the states' sales factors and make a new prediction.22

[FIGURE 1 ABOUT HERE]

Figure 1 shows the results from this exercise, which can be interpreted as illustrating the effect of a large change in the whole competitive environment, or of a long-run ratcheting up process that affects all states simultaneously. Two main conclusions emerge. First, when legislative professionalism is very low, responsiveness to changes in the competitive environment hovers around the null; semiprofessional legislatures do not appear to monitor and react in changes in others' policies. Second, the strength of the diffusion mechanism increases almost linearly in the professionalism index. For highly professional states, there is almost a oneto-one relationship between changes outside the state and changes inside the state. This finding is consistent with our argument that professionalism makes a state more likely to act upon external threats to its economic well-being in this complex policy area.

\subsection{Robustness}

We estimate several alternative models to address concerns and probe the robustness of our results. All robustness checks are reported in Tables A1 to A4 of the appendix.

To begin, we consider the most important potential confounders: ideological variables. If Republicans and Democrats hold different preferences over tax policy, and if there is geographic clustering in the ideological composition of state legislatures, then our main results may be a byproduct of omitted variable bias. To guard against this possibility, the second model of Table 1 controls for several political variables: the party of the Governor, the percentage of a state's senate that is controlled by Democrats, and the percentage of a state's house that is controlled by Democrats.

\footnotetext{
${ }^{22}$ Because the $W$ matrix has zeros on the diagonal, a state's own sales weight at $t-1$ does not enter into the calculation of its predicted sales weights at $t$. Thus, adding 25 to the sales weight of each state does not affect the results presented in Figure 1.
} 
A unified government dummy variable also captures the ease with which state governments can adjust corporate tax apportionment formulas.

Another potential confounding factor is gubernatorial power. As several authors have recently pointed out, governors can have a strong influence on the budget process, even if their proposals must navigate the legislative process (Krause and Melusky, 2012; Kousser and Phillips, 2012). This raises legitimate questions about the role of executive power in formula-based tax competition. To ensure that our empirical results are not skewed by this, The appendix shows results from regression models which include a control for "unilateral executive control over fiscal policymaking and fiscal-spending growth" (Krause and Melusky, 2012).

In the exploratory data analysis section, we explained that the sales weight is a continuous variable. But while it is true that states could theoretically choose any value on the 0 to 100 interval, in practice, they tend adopt one of three tax "regimes": equal (1/3), double (1/2), or sales-only (1). To take this into account, we recode the sales weight as an ordinal variable 33 and re-estimate the baseline models. Also, because our dependent variables could be thought of as continuous but censored (between 33 and 100), we estimate a Tobit model. Yet another approach is to recode the dependent variable such that any increase in sales weight corresponds a binary event, and to treat those events in a duration framework using the Cox Proportional Hazards model. These three tests are presented in appendix.

The baseline models shown above were estimated in a sample that excludes states without a corporate income tax. One way to bring these states back into the analysis is to code each of them as having a $100 \%$ weight on the sales factor. Indeed, as we explained above, increasing the sales weight converts the corporate income tax into what is effectively a sales tax (McLure, 1980). In general, states that do not use a corporate income tax must rely on other forms of revenues such as sales taxes to finance their operations. In that sense, the structure of their tax system is akin to that of states that use $100 \%$ weight on the sales factor. In appendix, we estimate models which include all states, filling in values of the sales weight with 100 when a state does not have a corporate income tax.

It is also important to recognize that the Squire index of professionalism that we use as our main conditioning variable is a rather crude empirical proxy for the specific resources that faciliate legislative response to tax competition. For instance, this index ignores important factors like the frequency of interactions between legislators and staff, as well as the quality of those interactions. While developing a new measure of professionalism that better approximates our theory lies outside the scope of this paper, it is possible to conduct a more fine-grained analysis by disaggregating the Squire index into its three constituent parts: staff size, session length,

\footnotetext{
${ }^{23}$ The re-coded ordinal variable takes on a value of 1 for equal weights, 2 for values on the ]33, 50[ interval, 3 for 50, 4 for ]50, 100[, and 5 for 100 .
} 
and legislator salary. Table A3 shows results using these alternative measures as our conditioning variable. Staff sizes, session lengths, and salaries all appear to play a positive role in facilitating diffusion. This is broadly consistent with our theory, which hanged on the capacity-augmenting nature of legislative professionalism.

Finally, we address four issues related to model specification and estimation. (1) While it is common in this literature to estimate spatial OLS models of the form described above (here we follow Neumayer and Plümper (2012)), several authors have noted that such models can be subject to endogeneity bias (e.g. Beck, Gleditsch and Beardsley, 2006). To guard against this possibility, we re-estimate our baseline model using the spatial maximum likelihood (S-ML) described in Franzese and Hays (2007).24 (2) We re-estimate the baseline models with both state fixed effects and a lagged dependent variable. (3) We control for time trends by including controls for the year and its square. (4) We compute different types of standard errors for our baseline models (heteroskedasticity-consistent, state, and year-clustered).

The results from all robustness tests are reported in the online appendix. Our subjective assessment is that, while the magnitude of estimated marginal effects varies considerably across specifications, it remains substantively high, of the expected direction, and statistically significant.25

\section{DISCUSSION}

In this paper, we showed that US states engage in tax competition by increasing the sales component of their apportionment formulas. Using spatial econometric techniques, we also presented evidence that a legislature's reaction to other states'

\footnotetext{
${ }^{24}$ Because of the multiplicative interaction, our model can be seen as including two distinct spatial weights matrices: the $W$ matrix itself, and a $W$ matrix which was multiplied by a Squire index column vector. Unfortunately, we are aware of no off-the-shelf (and well-tested) software implementation of the S-ML model which can accommodate two sets of weights. Thus, we used an adapted version of Stata code provided by Hays. For computational reasons we jointly normalize the spatial contiguity matrices as described in Beck, Gleditsch and Beardsley (2006, 35).

${ }^{25}$ One noteworthy exception to this conclusion is the model with both a lagged dependent variable and state fixed effects. There, the main coefficient of interest - the interaction between Diffusion and Professionalism - remains of the expected sign. However, the constituent term for Diffusion takes on a rather large negative value such that, for most observed values of the Squire index, the model shows no evidence of cross-state diffusion in tax policy. This suggests that caution in interpretation is warranted, but the result should not be over-interpreted. Indeed, the idea that states' tax policies are not interdependent is at odds with a vast body of work in public finance, with much of the anecdotal evidence that we uncovered in preparation for this paper, and with the visual pattern shown in Figure 2. One potential explanation for the counter-intuitive finding is that both of our regressors of interest (professionalism and spatial dependence) are very sticky over time, and that there is relatively little variation in our dependent variable; we rarely observe more than one change within a state during the sampling period. In that context, a fixed effects (i.e., within) model with lagged dependent variable is an extremely demanding specification.
} 
policies is conditioned by its degree of professionalism: when a policy is not highly visible, and when its effects are uncertain and hard to ascertain, policymakers must expend a lot of resources to observe, understand, and assess the policies of rival states to inform their own decision-making. High-capacity legislatures are better positioned to do this, and are more likely to respond to rivals' policies in order to redress competitive balance. This finding has several important implications for our understanding of both tax competition and legislative behavior.

The first set of implications pertains to the use of formulary apportionment in the fight against corporate tax avoidance. In recent years, several scandals have drawn attention to the aggressive tax minimization strategies of multinationals. ${ }^{26}$ Given the scale of the tax haven problem - Zucman (2015) estimates that \$7.6 trillions are held offshore - many analysts and activists consider that fundamental reform of the international tax system is necessary. Several economists and legal scholars have argued that formulary apportionment could be the cornerstone of a promising reform agenda.27

The findings in this paper can help us assess the feasability of different apportionment systems, both in federations and at the international level. Indeed, the US experience shows that in the absence of strong coordination between legislators in different jurisdictions, competition is likely to produce convergence toward a singlesales apportionment factor. This has major implications for the distribution of the fiscal burden since, as we have seen above, corporate income taxes that are apportioned without regard for the geographic distribution of payroll and capital act as a sort of sales tax. One obvious concern is that this type of tax could be more regressive than those currently in place in most countries.

This is not to say that coordination around a different set of weights is impossible. In Canada, for example, provinces have long use a common formula, but this cooperative outcome came in a very particular institutional context: most of the Canadian provinces delegate the administration and collection of their corporate income taxes to the federal government (Krchniva, 2014). When the European Commission proposed the adoption of a EU-wide formulary apportionment system (under the Common Consolidated Tax Base initiative) it, perhaps wisely, sidestepped the problem by suggesting that each country adopt a single-sales formula from the outset. But again, the distributional concerns remain.

Moving beyond the narrow problem for apportionment formula design, our work also highlights the fact that governments can deploy a slew of instruments when they compete to attract investment. Even if legislatures are politically constrained in their ability to change headline tax rates, the complexity of the tax code allows them to compete over less visible policies like apportionment formulas. More

\footnotetext{
${ }^{26}$ Consider, for example, the caches of documents published by the International Consortium of Investigative Journalists under the names "LuxLeaks" and "Panama Papers": http://icij.org

${ }^{27}$ Dietsch (2015), Avi-Yonah, Clausing and Durst (2008), Dietsch and Rixen (2016)
} 
generally, this means that professionalized legislatures can tap an important source of comparative advantage over semi-professional legislatures, by deploying their knowhow to adjust policy in understudied, complex, and more opaque issue areas.

The above suggests an economic rationale for making investments in legislative capacity. Indeed, a state who seeks to improve its competitiveness relative to rival jurisdictions could benefit from improving the professionalism of its legislature, since this could allow it to act more quickly to redress competitive imbalance in highly technical legislative fields such as tax policy.

The present work also shows that, in cases involving cross-state competition, legislative professionalism can increase jurisdictional interdependence, by facilitating emulation. The reverse is also true: state legislatures with low informational capacity make more insular policy choices. As a result, the lack of legislative professionalism can increase friction in interstate competition, and slow down policy convergence. Our finding linking legislative professionalism to increased state responsiveness to economic challenges is important and represents an extension of previous research linking professionalism to increased diffusion in areas where states are cooperative and not necessarily rivals of one another. Our finding could reasonably apply to policy areas where races to the bottom could occur and a fruitful extension of this work could analyze the role of legislative professionalism-moderated competition in environmental or welfare policy.

One specific issue area where our theory may have explanatory power is the formulation and adoption of state land use policy. States utilize land use policies in order to manage development and maintain a sound quality of life for residents. However, overly stringent land use policies may negatively impact economic development and encourage firms and even some residents to locate elsewhere. States therefore have the task of devising land use policies that strike a balance between promoting quality of life without chasing away businesses and residents to other states. States with professional legislatures may more quickly learn about and embrace a mix of land use best practices that promote quality of life without hampering economic development while states with semi-professional legislatures may have a mix of more insular land use policies that do not achieve the same quality of life/economic development balance. More generally, our theory extends to issue areas where states view each other as competitors and where the issue is highly technical in nature.

Lastly, the results presented herein show that the diffusion of policies across legislatures should not be thought of as uniform or unconditional. Rather, the institutional characteristics of legislatures affect how responsive those legislatures are to developments in other states.

Legislative scholars could build on these insights to illuminate several other important problems. For instance, one could extend the analysis and evaluate whether legislative professionalism moderates states' responsiveness to federal laws, regula- 
tions, and grant programs. Alternatively, scholars could study the factors that facilitate policy diffusion in semi-professional legislatures: given their resource constraints, members of semi-professional legislatures may need to rely on networks like the National Conference of State Legislatures 28 or lobbyists (Hall and Deardorff, 2006) to bridge the "knowledge gap" and serve as catalysts of policy diffusion. Future work in either of these directions would add to our knowledge about the legislative determinants of policy diffusion.

\footnotetext{
${ }^{28}$ Organizations like the NCSL play an important role in facilitating the collection, analysis, and dissemination of complex information. By giving legislators access to policy briefs and expert commentary, they reduce the asymmetry in information capacity between professional and semi-professional legislatures. In a world where the NCSL did not exist, we would thus expect the conditioning effect of professionalism on policy diffusion to be even stronger that what we observed here.
} 


\section{REFERENCES}

Anand, Bharat N and Richard Sensing. 2000. "The weighting game: formula apportionment as an instrument of public policy." National Tax Journal pp. 183-199.

Avi-Yonah, Reuven S., Kimberly A. Clausing and Michael C. Durst. 2008. "Allocating Business Profits for Tax Purposes: A Proposal to Adopt a Formulary Profit Split." Fla. Tax Rev. 9:497.

Beck, Nathaniel, Kristian Skrede Gleditsch and Kyle Beardsley. 2006. "Space Is More than Geography: Using Spatial Econometrics in the Study of Political Economy." International Studies Quarterly 50(1):27-44.

Berry, Frances Stokes and William D Berry. 1990. "State lottery adoptions as policy innovations: An event history analysis." American political science review 84(02):395-415.

Berry, William D and Brady Baybeck. 2005. "Using geographic information systems to study interstate competition." American Political Science Review 99(04):505519.

Berry, William D, Richard C Fording, Evan J Ringquist, Russell L Hanson and Carl Klarner. 2013. "A new measure of state government ideology, and evidence that both the new measure and an old measure are valid." State Politics \& Policy Quarterly 13(2):164-182.

Boushey, Graeme. 2010. Policy diffusion dynamics in America. Cambridge University Press.

Carter, Larry E and James T LaPlant. 1997. "Diffusion of health care policy innovation in the United States." State \& Local Government Review pp. 17-26.

Case, Anne C., Harvey S. Rosen and James R. Hines. 1993. "Budget spillovers and fiscal policy interdependence: Evidence from the states." Journal of public Economics 52(3):285-307.

Desmarais, Bruce A, Jeffrey J Harden and Frederick J Boehmke. 2015. "Persistent Policy Pathways: Inferring Diffusion Networks in the American States." American Political Science Review 109(02):392-406.

Dietsch, Peter. 2015. Catching Capital: The Ethics of Tax Competition. Oxford University Press.

Dietsch, Peter and Thomas Rixen. 2016. Global Tax Governance: What's Wrong, and How to Fix It. ECPR Press. 
Edmiston, Kelly D. 2002. "Strategic apportionment of the state corporate income tax: An applied general equilibrium analysis." National Tax Journal pp. 239-262.

Franzese, Robert J. and Jude C. Hays. 2007. "Spatial Econometric Models of CrossSectional Interdependence in Political Science Panel and Time-Series-CrossSection Data." Political Analysis 15(2):140-164.

Goolsbee, Austan and Edward L. Maydew. 2000. "Coveting thy neighbor's manufacturing: the dilemma of state income apportionment." Journal of Public Economics 75(1):125-143.

Gordon, Roger and John D Wilson. 1986. "An examination of multijurisdictional corporate income taxation under formula apportionment." Econometrica: Journal of the Econometric Society pp. 1357-1373.

Gupta, Sanjay, Jared Moore, Jeffrey Gramlich and Mary Ann Hofmann. 2009. "Empirical evidence on the revenue effects of state corporate income tax policies." $\mathrm{Na}$ tional Tax Journal pp. 237-267.

Gupta, Sanjay and Mary Ann Hofmann. 2003. "The Effect of State Income Tax Apportionment and Tax Incentives on New Capital Expenditures." The Journal of the American Taxation Association 25(s-1):1-25.

Hall, Richard L and Alan V Deardorff. 2006. "Lobbying as legislative subsidy." American Political Science Review 100(1):69-84.

Hannah, James. 2006. "Ohio, Indiana Vying to Lure Honda..

URL: http://www.washingtonpost.com/wp-dyn/content/article/ 2006/05/21/AR2006052100476_pf.html

Hines, Jr., James R. 2010. "Income misattribution under formula apportionment." European Economic Review 54(1):108-120.

Illinois Economic and Fiscal Commission. 2002. Illinois' Corporate Income Tax. Technical report State of Illinois.

URL: $h t t p: / / c g f a . i l g a . g o v / U p l o a d / I L \_C o r p \_I n c o m e \_T a x . p d f$

Joint Committee on Taxation. 2010. Present law and background related to possible income shifting and transfer pricing.

Klassen, Kenneth J and Douglas A Shackelford. 1998. "State and provincial corporate tax planning: income shifting and sales apportionment factor management." Journal of Accounting and Economics 25(3):385-406.

Kousser, Thad and Justin H. Phillips. 2012. The power of American governors: Winning on budgets and losing on policy. Cambridge University Press. 
Krause, George A. and Benjamin F. Melusky. 2012. "Concentrated Powers: Unilateral Executive Authority and Fiscal Policymaking in the American States." The Journal of Politics 74(01):98-112.

Krchniva, Katerina. 2014. "Comparison of European, Canadian and U.S. Formula Apportionment on Real Data." Procedia Economics and Finance 12:309-318.

Krugman, Paul. 1991. "Increasing Returns and Economic Geography." The Journal of Political Economy 99(3):483-499.

Maynard, Micheline. 2006. "Indiana Wins the Bidding for New Honda Assembly Plant - New York Times..

URL: http://www.nytimes.com/2006/06/29/automobiles/29honda. html?_r=0

McCoy, Dennis. 1999. Opposition to House bill 11. Prepared on Behalf of KraftPhilip Morris.

McLure, Charles E. Jr. 1980. The State Corporate Income Tax: Lambs in Wolves' Clothing. In The Economics of Taxation. The Brookings Institution.

Michigan House Fiscal Agency. 2017. “About Us." http://www.house.mi.gov/ hfa/About.asp.

Michigan Senate Fiscal Agency. 2017a. "About Us." http://www.senate. michigan.gov/sfa/AboutUs/AboutUs.html.

Michigan Senate Fiscal Agency. 2017b. "Organizational Chart." http://www. house.mi.gov/hfa/PDF/HFA_orgchart.pdf.

Mossberger, Karen. 2000. The politics of ideas and the spread of enterprise zones. Georgetown University Press.

Neumayer, Eric and Thomas Plümper. 2012. "Conditional Spatial Policy Dependence Theory and Model Specification." Comparative Political Studies 45(7):819849.

New Hampshire Department of Revenue Administration. 2014. "Sourcing of Sales Apportionment Factor of the New Hampshire Business Profits Tax." http://www.revenue.nh.gov/publications/presentations/ documents/sourcing-of-sales.pdf. Presentation to the House Ways and Means Committee.

Omer, Thomas C and Marjorie K Shelley. 2004. "Competitive, political, and economic factors influencing state tax policy changes." Journal of the American Taxation Association 26(s-1):103-126. 
Pacheco, Julianna. 2012. "The social contagion model: exploring the role of public opinion on the diffusion of antismoking legislation across the American states." The Journal of Politics 74(01):187-202.

Peterson, Paul E and Mark C Rom. 1990. "Welfare Magnets: A Case for a National Welfare Standard.”.

Pinto, Santiago M. 2007. "Corporate profit tax, capital mobility, and formula apportionment." Journal of Urban Economics 62(1):76-102.

Plümper, Thomas, Vera E Troeger and Hannes Winner. 2009. "Why is There No Race to the Bottom in Capital Taxation?" International Studies Quarterly 53(3):761786 .

Porter, Michael E. 1998. Clusters and competition: new agendas for companies, governments, and institutions. Harvard Business School Press.

Riedel, Nadine and Marco Runkel. 2007. "Company tax reform with a water's edge." Journal of Public Economics 91(7):1533-1554.

Rom, Mark Carl, Paul E Peterson and Kenneth F Scheve. 1998. "Interstate competition and welfare policy." Publius: The Journal of Federalism 28(3):17-37.

Shipan, Charles and Craig Volden. 2006. "Bottom-Up Federalism: The Diffusion of Antismoking Policies from U.S. Cities to States." American Journal of Political Science 50(4):825-843.

Shipan, Charles and Craig Volden. 2008. "The mechanisms of policy diffusion." American journal of political science 52(4):840-857.

Shipan, Charles and Craig Volden. 2014. "When the smoke clears: expertise, learning and policy diffusion." Journal of Public Policy 34(03):357-387.

Squire, Peverill. 2007. "Measuring State Legislative Professionalism: The Squire Index Revisited." State Politics \& Policy Quarterly 7(2):211-227.

Volden, Craig. 2002. "The politics of competitive federalism: A race to the bottom in welfare benefits?” American Journal of Political Science pp. 352-363.

Volden, Craig. 2006. "States as Policy Laboratories: Emulating Success in the Children's Health Insurance Program." American Journal of Political Science 50(2):294-312.

Walker, Jack L. 1969. "The diffusion of innovations among the American states." American political science review 63(03):880-899. 
Weiner, Joann M. 1999. Using the Experience in the U.S. States to Evaluate Issues in Implementing Formula Apportionment at the International Level. OTA Paper 83 US Department of the Treasury.

Wellisch, Dietmar. 2004. "Taxation under formula apportionment-tax competition, tax incidence, and the choice of apportionment factors." FinanzArchiv/Public Finance Analysis pp. 24-41.

Zucman, Gabriel. 2015. The hidden wealth of nations: The scourge of tax havens. University of Chicago Press. 
TABLES AND FIGURES 
Figure 1: Expected response to a 25 percentage points increase in other states' sales factor weight.

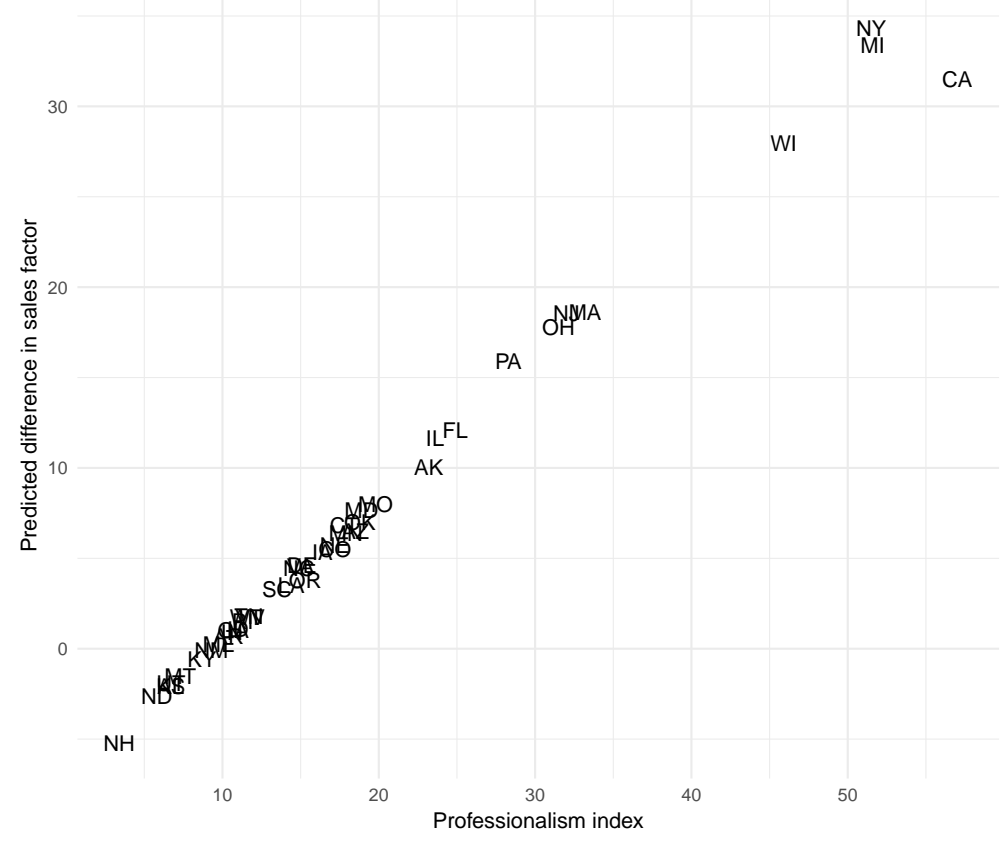


Table 1: Conditional spatial diffusion of tax policy in the American states.

\begin{tabular}{|c|c|c|c|c|c|c|}
\hline & OLS 1 & OLS 2 & FE 1 & FE 2 & Lag 1 & Lag 2 \\
\hline (Intercept) & $\begin{array}{c}-11.051 \\
(9.024)\end{array}$ & $\begin{array}{c}-27.881 \\
(8.086)\end{array}$ & $\begin{array}{c}-169.698 \\
(34.693)\end{array}$ & $\begin{array}{c}-162.892 \\
(35.362)\end{array}$ & $\begin{array}{l}-1.126 \\
(2.361)\end{array}$ & $\begin{array}{l}-2.720 \\
(2.405)\end{array}$ \\
\hline $\log (G D P)$ & $\begin{array}{c}5.355 \\
(0.667)\end{array}$ & $\begin{array}{c}6.521 \\
(0.643)\end{array}$ & $\begin{array}{l}19.280 \\
(3.575)\end{array}$ & $\begin{array}{l}18.320 \\
(3.568)\end{array}$ & $\begin{array}{c}0.434 \\
(0.209)\end{array}$ & $\begin{array}{c}0.540 \\
(0.226)\end{array}$ \\
\hline Log(Unemployment) & $\begin{array}{l}-2.753 \\
(2.346)\end{array}$ & $\begin{array}{c}4.461 \\
(2.248)\end{array}$ & $\begin{array}{c}9.787 \\
(1.711)\end{array}$ & $\begin{array}{l}10.077 \\
(1.734)\end{array}$ & $\begin{array}{l}-0.206 \\
(0.556)\end{array}$ & $\begin{array}{c}0.320 \\
(0.596)\end{array}$ \\
\hline W & $\begin{array}{c}0.078 \\
(0.126)\end{array}$ & $\begin{array}{l}-0.011 \\
(0.124)\end{array}$ & $\begin{array}{l}-0.344 \\
(0.178)\end{array}$ & $\begin{array}{l}-0.311 \\
(0.176)\end{array}$ & $\begin{array}{l}-0.046 \\
(0.036)\end{array}$ & $\begin{array}{l}-0.044 \\
(0.037)\end{array}$ \\
\hline Professionalism & $\begin{array}{l}-1.830 \\
(0.182)\end{array}$ & $\begin{array}{l}-1.920 \\
(0.182)\end{array}$ & $\begin{array}{l}-1.767 \\
(0.277)\end{array}$ & $\begin{array}{l}-1.695 \\
(0.278)\end{array}$ & $\begin{array}{l}-0.178 \\
(0.070)\end{array}$ & $\begin{array}{l}-0.185 \\
(0.073)\end{array}$ \\
\hline $\mathrm{W} \times$ Professionalism & $\begin{array}{c}0.041 \\
(0.004)\end{array}$ & $\begin{array}{c}0.041 \\
(0.004)\end{array}$ & $\begin{array}{c}0.036 \\
(0.006)\end{array}$ & $\begin{array}{c}0.035 \\
(0.006)\end{array}$ & $\begin{array}{c}0.004 \\
(0.002)\end{array}$ & $\begin{array}{c}0.004 \\
(0.002)\end{array}$ \\
\hline Unified government & & $\begin{array}{l}-0.645 \\
(1.217)\end{array}$ & & $\begin{array}{c}2.599 \\
(0.785)\end{array}$ & & $\begin{array}{c}0.090 \\
(0.333)\end{array}$ \\
\hline Dem. Governor & & $\begin{array}{l}-0.510 \\
(1.211)\end{array}$ & & $\begin{array}{l}-1.254 \\
(0.755)\end{array}$ & & $\begin{array}{l}-0.130 \\
(0.286)\end{array}$ \\
\hline Dem. Senate \% & & $\begin{array}{c}1.268 \\
(6.057)\end{array}$ & & $\begin{array}{l}-3.577 \\
(4.609)\end{array}$ & & $\begin{array}{c}0.195 \\
(1.662)\end{array}$ \\
\hline Dem. House \% & & $\begin{array}{l}-9.676 \\
(6.607)\end{array}$ & & $\begin{array}{c}5.399 \\
(6.029)\end{array}$ & & $\begin{array}{l}-1.010 \\
(1.898)\end{array}$ \\
\hline Sales weight $t_{t-1}$ & & & & & $\begin{array}{c}0.983 \\
(0.007)\end{array}$ & $\begin{array}{c}0.979 \\
(0.008)\end{array}$ \\
\hline$\overline{\mathrm{R}^{2}}$ & 0.203 & 0.246 & 0.788 & 0.783 & 0.954 & 0.952 \\
\hline Num. obs. & 1153 & 1126 & 1153 & 1126 & 1153 & 1126 \\
\hline
\end{tabular}


Figure 2: Historical evolution of formula weights across all US States.

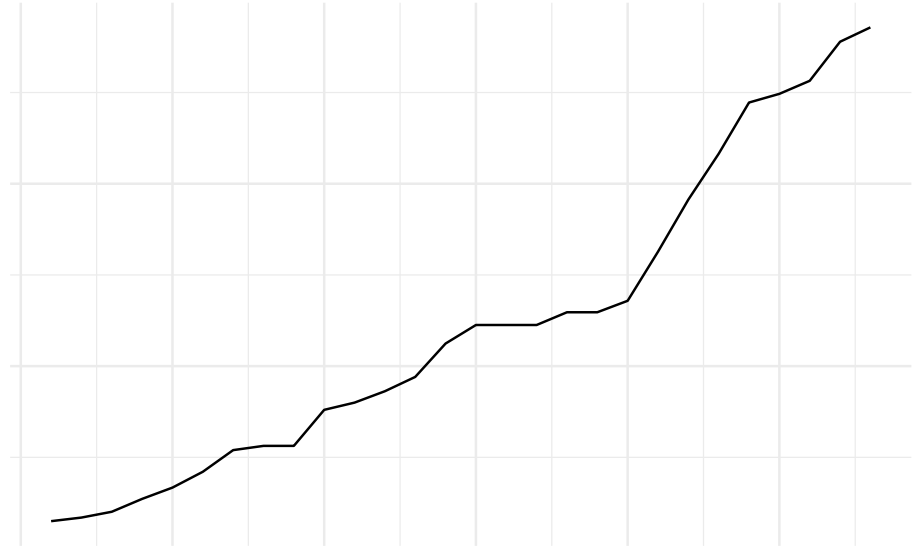

Figure 3: Sales apportionment weights in 2012. States in white are excluded from the analysis.

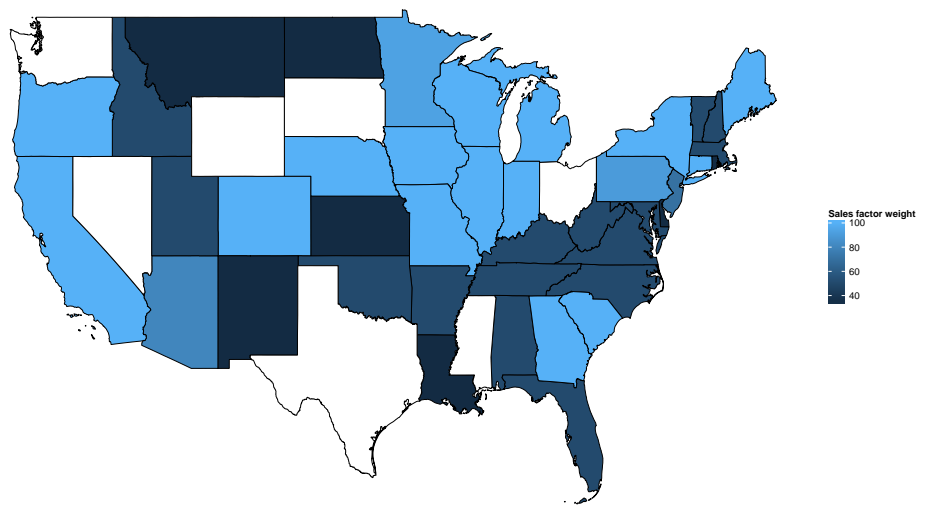




\section{SUPPLEMENTARY MATERIAL}


Table A1: Robustness checks. (1 of 4 )

\begin{tabular}{lcccccc}
\hline & W Econ.1 & W Econ.2 & W Ideol.1 & W Ideol.2 & W Ideol.3 & W Partisan \\
\hline Intercept) & -127.823 & -96.017 & -151.853 & -124.611 & -145.700 & -252.562 \\
& $(35.406)$ & $(35.014)$ & $(35.161)$ & $(35.253)$ & $(35.859)$ & $(27.180)$ \\
$\log (\mathrm{GDP})$ & 14.294 & 11.058 & 17.034 & 14.011 & 16.281 & 25.782 \\
& $(3.757)$ & $(3.653)$ & $(3.738)$ & $(3.743)$ & $(3.831)$ & $(2.612)$ \\
$\log ($ Unemployment) & 7.683 & 6.985 & 8.675 & 7.608 & 8.626 & 10.351 \\
& $(1.703)$ & $(1.662)$ & $(1.709)$ & $(1.700)$ & $(1.695)$ & $(1.774)$ \\
$\mathrm{W}$ & -0.145 & 0.048 & -0.294 & -0.134 & -0.254 & -0.163 \\
& $(0.196)$ & $(0.183)$ & $(0.198)$ & $(0.198)$ & $(0.203)$ & $(0.155)$ \\
Professionalism & -1.687 & -1.623 & -1.795 & -1.726 & -1.782 & -0.684 \\
& $(0.257)$ & $(0.252)$ & $(0.258)$ & $(0.263)$ & $(0.265)$ & $(0.360)$ \\
W $\times$ Professionalism & 0.039 & 0.036 & 0.042 & 0.040 & 0.041 & 0.015 \\
& $(0.006)$ & $(0.006)$ & $(0.006)$ & $(0.006)$ & $(0.006)$ & $(0.009)$ \\
\hline $\mathrm{R}^{2}$ & 0.793 & 0.792 & 0.793 & 0.793 & 0.792 & 0.814 \\
Num. obs. & 1153 & 1153 & 1153 & 1153 & 1153 & 872 \\
\hline
\end{tabular}

Heteroskedasticity-consistent standard errors in parentheses. 
Table A2: Robustness checks. (2 of 4)

\begin{tabular}{|c|c|c|c|c|c|c|}
\hline & W DHB 1 & W DHB 2 & Gov.Power 1 & Gov.Power 2 & Time Trend & Lag, FE \\
\hline (Intercept) & $\begin{array}{c}-168.667 \\
(33.800)\end{array}$ & $\begin{array}{c}-199.965 \\
(30.989)\end{array}$ & $\begin{array}{c}-158.246 \\
(34.085)\end{array}$ & $\begin{array}{c}-113.375 \\
(33.552)\end{array}$ & $\begin{array}{l}181.082 \\
(49.877)\end{array}$ & $\begin{array}{l}-23.542 \\
(17.312)\end{array}$ \\
\hline $\log (\mathrm{GDP})$ & $\begin{array}{l}19.268 \\
(3.295)\end{array}$ & $\begin{array}{c}22.241 \\
(3.025)\end{array}$ & $\begin{array}{c}17.976 \\
(3.530)\end{array}$ & $\begin{array}{c}15.271 \\
(3.669)\end{array}$ & $\begin{array}{l}-7.477 \\
(4.750)\end{array}$ & $\begin{array}{c}2.818 \\
(1.833)\end{array}$ \\
\hline Log(Unemployment) & $\begin{array}{c}9.423 \\
(1.842)\end{array}$ & $\begin{array}{l}10.848 \\
(1.789)\end{array}$ & $\begin{array}{c}9.850 \\
(1.692)\end{array}$ & $\begin{array}{c}2.427 \\
(1.500)\end{array}$ & $\begin{array}{c}6.756 \\
(1.709)\end{array}$ & $\begin{array}{c}0.582 \\
(0.910)\end{array}$ \\
\hline W & $\begin{array}{l}-0.267 \\
(0.157)\end{array}$ & $\begin{array}{l}-0.351 \\
(0.134)\end{array}$ & $\begin{array}{l}-0.310 \\
(0.178)\end{array}$ & $\begin{array}{l}-0.123 \\
(0.234)\end{array}$ & $\begin{array}{l}-2.527 \\
(0.261)\end{array}$ & $\begin{array}{l}-0.116 \\
(0.095)\end{array}$ \\
\hline Professionalism & $\begin{array}{l}-1.641 \\
(0.279)\end{array}$ & $\begin{array}{l}-1.613 \\
(0.272)\end{array}$ & $\begin{array}{l}-1.695 \\
(0.276)\end{array}$ & $\begin{array}{l}-0.963 \\
(0.322)\end{array}$ & $\begin{array}{l}-1.513 \\
(0.269)\end{array}$ & $\begin{array}{l}-0.345 \\
(0.205)\end{array}$ \\
\hline $\mathrm{W} \times$ Professionalism & $\begin{array}{c}0.032 \\
(0.006)\end{array}$ & $\begin{array}{c}0.029 \\
(0.005)\end{array}$ & $\begin{array}{c}0.035 \\
(0.006)\end{array}$ & $\begin{array}{c}0.016 \\
(0.008)\end{array}$ & $\begin{array}{c}0.031 \\
(0.006)\end{array}$ & $\begin{array}{c}0.008 \\
(0.005)\end{array}$ \\
\hline Amendment power & & & $\begin{array}{c}4.378 \\
(1.900)\end{array}$ & $\begin{array}{c}4.313 \\
(1.713)\end{array}$ & & \\
\hline New Governor & & & $\begin{array}{l}-0.752 \\
(1.302)\end{array}$ & $\begin{array}{l}-1.933 \\
(0.997)\end{array}$ & & \\
\hline Gubernatorial power & & & & $\begin{array}{l}-5.208 \\
(1.169)\end{array}$ & & \\
\hline Year & & & & & $\begin{array}{c}1.362 \\
(0.298)\end{array}$ & \\
\hline Year $^{2}$ & & & & & $\begin{array}{c}0.047 \\
(0.008)\end{array}$ & \\
\hline sales $_{t-1}$ & & & & & & $\begin{array}{c}0.918 \\
(0.025)\end{array}$ \\
\hline $\mathrm{R}^{2}$ & 0.790 & 0.787 & 0.789 & 0.853 & 0.809 & 0.957 \\
\hline Num. obs. & 1153 & 1153 & 1153 & 943 & 1153 & 1153 \\
\hline
\end{tabular}

Heteroskedasticity-consistent standard errors in parentheses. 
Table A3: Robustness checks. (3 of 4)

\begin{tabular}{lcccccc}
\hline & Staff & S.Length & Salary & Homoskedastic & White & PCSE \\
\hline (Intercept) & -103.364 & -31.104 & -160.050 & -169.698 & -169.698 & -169.698 \\
& $(36.684)$ & $(46.709)$ & $(36.445)$ & $(31.711)$ & $(76.735)$ & $(81.467)$ \\
$\log (\mathrm{GDP})$ & 23.776 & 20.358 & 19.714 & 19.280 & 19.280 & 19.280 \\
& $(3.698)$ & $(3.589)$ & $(3.640)$ & $(3.277)$ & $(7.553)$ & $(8.377)$ \\
$\log$ (Unemployment) & 8.679 & 9.494 & 9.162 & 9.787 & 9.787 & 9.787 \\
& $(1.783)$ & $(1.681)$ & $(1.695)$ & $(1.515)$ & $(3.576)$ & $(3.023)$ \\
$\mathrm{W}$ & -2.053 & -3.080 & -0.695 & -0.344 & -0.344 & -0.344 \\
& $(0.380)$ & $(0.711)$ & $(0.193)$ & $(0.151)$ & $(0.378)$ & $(0.436)$ \\
Professionalism & -26.192 & -37.912 & -13.881 & -1.767 & -1.767 & -1.767 \\
& $(3.434)$ & $(6.944)$ & $(2.210)$ & $(0.191)$ & $(0.620)$ & $(0.633)$ \\
W $\times$ Professionalism & 0.425 & 0.713 & 0.304 & 0.036 & 0.036 & 0.036 \\
& $(0.062)$ & $(0.146)$ & $(0.045)$ & $(0.004)$ & $(0.012)$ & $(0.014)$ \\
\hline $\mathrm{R}^{2}$ & 0.795 & 0.781 & 0.781 & 0.788 & 0.788 & 0.788 \\
Num. obs. & 1110 & 1153 & 1153 & 1153 & 1153 & 1153 \\
\hline
\end{tabular}

Heteroskedasticity-consistent standard errors in parentheses.

Table A4: Robustness checks. (4 of 4)

\begin{tabular}{lcc}
\hline & Clust.State & Clust.Year \\
\hline (Intercept) & -169.698 & -169.698 \\
& $(76.735)$ & $(34.860)$ \\
$\log (\mathrm{GDP})$ & 19.280 & 19.280 \\
& $(7.553)$ & $(3.553)$ \\
$\log ($ Unemployment) & 9.787 & 9.787 \\
& $(3.576)$ & $(1.726)$ \\
$\mathrm{W}$ & -0.344 & -0.344 \\
& $(0.378)$ & $(0.147)$ \\
Professionalism & -1.767 & -1.767 \\
& $(0.620)$ & $(0.192)$ \\
W $\times$ Professionalism & 0.036 & 0.036 \\
& $(0.012)$ & $(0.005)$ \\
\hline R & 0.788 & 0.788 \\
Num. obs. & 1153 & 1153 \\
\hline Heteroskedasticity-consistent standard errors in parentheses.
\end{tabular}


Table A5: Descriptive statistics

\begin{tabular}{rrrrr}
\hline & min & median & $\max$ & $\mathrm{sd}$ \\
\hline demgovernor & 0.00 & 0.00 & 1.00 & 0.50 \\
demhousepercentage & 0.13 & 0.54 & 0.93 & 0.16 \\
demsenatepercentage & 0.09 & 0.52 & 0.97 & 0.17 \\
gdp & 9.55 & 11.87 & 14.54 & 1.06 \\
sales & 33.00 & 50.00 & 100.00 & 23.22 \\
sales_increase & 0.00 & 0.00 & 1.00 & 0.24 \\
sales_lag & 33.00 & 50.00 & 100.00 & 22.81 \\
squire & 2.70 & 16.40 & 65.90 & 12.90 \\
state $^{*}$ & $\mathrm{Inf}$ & & $-\mathrm{Inf}$ & \\
ugov & 0.00 & 0.00 & 1.00 & 0.50 \\
W & 29.30 & 45.50 & 65.57 & 7.56 \\
\hline unemployment & 0.83 & 1.69 & 2.62 & 0.33 \\
\hline
\end{tabular}

